\title{
Changing leadership in peripheral city region development: The case of Liverpool's high technology sectors
}

\author{
Dane Anderton \\ Manchester Metropolitan University
}

\begin{abstract}
This article examines the effects of changing place leadership when developing knowledge intensive industries in a peripheral city region. This study examined the video games and life sciences industries in Liverpool City Region. Both have an established presence in the city region and are key to the city regions knowledge economy strategy. Few studies have examined why different types of regions experience diverse path-dependent development. By tracing the two high technology sectors back to their conception it has become apparent that the most significant developments have been between 2005 and 2015. During this period, the city region saw increased public intervention and underwent institutional change. The analysis highlights that the public and institutional leadership in the city region prior to 2010 managed to reinvigorate the industrial base and increase R\&D capacity in the high technology sectors and develop institutional assets to sustain growth in the region. The change in leadership post 2010 highlighted the life science industries dependence on public leadership and support, compared with the video games industry. There are still issues within the city regions labour market and concerns around the underdevelopment of soft infrastructures post 2010. If these sectors are to be resilient, policy makers need to improve the transition between leaders in regional development so that best practices and soft infrastructures are inherited, maintained or improved. Additionally, policy makers should also plan for the long-term engagement required when developing high technology sectors such as life sciences in peripheral city regions, where pathways to market carry uncertainty and demand for a highly qualified labour market is increased. The evidence is derived from 58 primary qualitative interviews with firms' own-managers and supporting institutions at a local and national scale. Secondary data both qualitative and quantitative has also been used to supplement the analysis and inform the broader context.
\end{abstract}


Key words: Leadership, Knowledge, Liverpool City Region (LCR), Path Dependence, Institutions, Change

\section{Introduction}

Leadership of place cannot be ignored in the context of economic development (Gibney, 2010; Collinge and Gibney, 2010). Leadership of place is one of the key factors explaining how some places show a particular tendency over time to adapt to new situations and exploit emerging opportunities (Sotarauta et al, 2012). There are places that lack such leadership meaning they fall behind and into a state of decline over a longer period. There are many cases of successful place leadership, where we see a transformation of localities and renewed growth pathways emerge in new path creation and adaption processes (OECD, 2015). Across Europe and particularly in the UK, there has been a noticeable change in the governance, policy and formal leadership of city regions. Under an age of austerity, city regions have to cope with increasing demands from business and citizens, leading them to rethink their approach to resilient economic development. Equally, the changes that are occurring are difficult to adjust too and can be the cause of decline or stalling in city regional development. Leadership is viewed as a multi-agency and multilevel activity within our regions, contrary to traditional notions of 'one man' war stories of positive leadership and change for the better (Liddle, 2016). Equally place leadership is shaped by the institutions and contexts in which it operates (Sotarauta and Beer, 2017).

This paper will consider the effects of changing leadership of place when developing knowledge intensive industries. The research sheds light on the changing multi-agency leadership that geared Liverpool towards economic development in the life sciences and video games industry. Leadership as a concept is bulging with research and debate, which in turn has made the concept somewhat contested and fuzzy (Bryman, 2004). Many articles on place leadership reference long-term network relationships, but few document what happens in the event of sudden change. We do not find many critical stories of leadership between two cases in the same place with opposing outcomes to leadership. The story is usually told after the event rather than throughout. History is usually lost in these account leaving them void of much of the historical contexuality, path dependencies and contingent linkages 
(Bathelt and Glückler, 2011). This research unpacks a case that is still in the making with some immediate lessons can be learned and observed for other regions.

This article thus asks the research question what effect has changes in place leadership had in Liverpool City Region's (LCR) development of two high technology sectors (life science and video games). The paper examines the case within LCR, an old industrial region that shifted its economic development path in 1980 from almost managed decline towards new digital/creativity- and science-based industries. Drawing on primary qualitative data the article concludes that leaders in LCR need to appreciate the varying effects of changing leadership on hard and soft infrastructure development, especially after embarking on capital-intensive industrial support. For non-capital intensive and mobile industries, such as the video games sector, private initiatives and leadership should be recognised as soon as possible and supported. Generally, place leaders need to consider carefully their choices when embarking on industrial renewal of city regions to ensure long-term sustainable economic development.

\section{Leadership and Regional Development}

City Regions are places where a variety of leadership forms and styles manifest themselves. Regional economic development is a multiagency and multidimensional phenomenon, requiring an understand of multiple factors and complex processes (Stimson et al, 2009). Equally, economic development, based on key industry growth, can no longer rely solely on traditional production factors such as land, labour and capital (Anderton, 2016). As a unit of analysis, the city region can host many expressions of leadership such as political, executive,

community and business. Beer and Clower (2014) argue that 'place leadership' is important for economic development. Unlike much of the literature that exists around leadership, cities do not change easily and can take long periods to transform for the better. Equally, understanding the impacts of leadership on places maybe the missing link as to why some places growth and sustain economic development and why other places may try but falter along the way (Rodríguez-Pose, 2013). Leadership within cities is complex and sometimes hard to pin down precisely (Liddle, 2015). There are formal, hidden and emerging leadership 
expressions acting across multiple scales. Recent literature has called for clarity in place leadership, making it clear what aspect of leadership is being examined (Sotarauta et al, 2017). This is not to privilege one over the other as we do find alternate distinct expressions of leadership in the same setting. Liddle et al (2016) argues that rather looking for one particular leader, we have to examine the broader contexts in which we see actions being played out.

Karlsen and Larra (2012) argue that place leadership is less about one individual, but more of a collective process of relationships and networks embedded in path dependency. There is a need to shed light on human agency within regional development and understand the contexts in which leadership is operating (Bristow et al, 2013). This strengthens the arguments that leadership of place is the missing link in understanding regional development. There is much more emphasis on the long-term relationship that develop in relation to place leadership, enriching them with context, path dependency and contingency (Bathelt and Glückler, 2011). The nature of these relationships is unknown in many cases due to their sensitive nature. Hence, when considering industrial developments supported and funded by public place leaders, it is important that hard infrastructures are able to create spaces whereby soft infrastructures such as networks can emerge and be built upon (Anderton, 2016).

Regional development cannot simply rely on good leaders it also requires a focus on how resilient those leaders are and how resilient the regions are to internal and external shocks and changes. Few studies have examined why different types of regions experience diverse development (Isaksen, 2015). If leadership is a missing link and impacts upon economic development of places and in turn industries located in the place, then leaders need to consider industry specific factors in development strategies. This is of high importance when considering support for knowledge-based sectors within an economic development framework and strategy for long-term sustainable growth. City region leaders must consider the wider innovation ecosystems in which they and the industry operate, recognising the contingent extra-local factors. In doing so leaders must link people, ideas, resources, networks and other elements to achieve development (Liddle, 2016). This in turn links to the relational approach to economic development. Understanding the contextulaity of place, the 
path dependency, and contingency factors from outside a locality that can affect the economic development of place. Neffke et al (2011:261) argues new trajectories of regional growth 'do not start from scratch but are strongly rooted in the historical economic structure of a region'. As noted above, the uncertainly in the global economy from a financial and political standpoint means leaders cannot ignore building resilience when embarking on new and existing growth strategies. Foster (2007:14) defines "regional resilience as the ability of a region to anticipate, prepare for, respond to, and recover from a disturbance". Simmie and Martin (2010) note that regions change and evolve to cope with shock and crisis. This is conceptualised as a large ecosystem with many different parts responding in different ways. Regional leaders must consider their industrial, technological, labour market and institutional abilities within the framework of economic development so that the industries that make up the region's economy can be sustainable and not become short-term expensive projects.

Huang and Xu (1999) and Cooke et al (2000) assert that government institutions do make a difference for regional development, typically yielding greater innovative and knowledge returns. The idea of institutions playing a key role in regional development is not new. Amin and Thrift (1994) conceptualised the idea of institutional thickness which can support local and regional development. The case of the Motor Sports Valley in the UK is an example of how overly thick regions can create institutional lock in leading to slow change and in turn limited resilience to internal and external shocks (Henry and Pinch, 2001). More recently Rodríguez-Pose and Di Cataldo (2015) have argued that strong institutions yield greater innovative returns in regions when considering knowledge related activities. A key issue in leadership is how we support the development of networks or soft infrastructures in industries situated within the city region. Linking together hard infrastructures with the soft infrastructures requires institutions with effective leaders to be able to broker relationships that connect multiple actors (Liddle, 2016). We can have multiple occupants in a city yet without a vision that understands the importance of developing soft infrastructures alongside the hard ones, the resilience of the ecosystem can be at risk.

Cities are not passive receivers of new global trends and need leaders to help them to take actions that make them fit within regional, national and global flows of capital and knowledge (Winden, 2008; Gibney, 2012). Pike et al (2006) sum up well by arguing local leaders must 
consider 'what kind of local and regional development, why and for whom?' Especially when considering knowledge intensive industries we must also consider how and why it emerges in particular places, how it is developed and what the broader impacts and influences are and can be. This paper will turn to the method and case used to explore the development of two knowledge economy industries within a peripheral city region, whilst considering the changes in leadership during the period $2005-2015$.

\section{Method and Case}

This paper examines the case study of the Liverpool City Region in the North West of England (see figure 1). In 2014, LCR had an economy of 1.5 million people, 38,000 VAT registered businesses worth $£ 25.3$ billion to the UK economy and has been one of the fastest growing UK regions outside of London (LCRLEP, 2014). Since the early 1990s, public money has been invested to developing new and existing industries in the city-region and bringing the city out of a state of economic and social decline (Southern, 2014). Recently, local economic development institutions formulated a knowledge economy strategy identifying the life science and digital/creative (more specifically video games) industries as two of four key sectors for development (LCR.co.uk, 2011). These two industries have been selected due to their high profile within the city region and high capital expenditure in comparison to the other knowledge intensive industries. In Liverpool the health and life sciences sector employs over 6000 people and is estimated to deliver products and services worth in excess of $£ 1.7$ billion per annum and contributes over $£ 300$ million in GVA (LCRLEPa, 2016). Equally, the digital/creative sector boasts an employment of almost 19,000 with a GVA of $£ 878 m$ (LCRLEP, 2016). Both industries have a history within Liverpool City Region, the life sciences being considerably longer and evolving from the chemical industry. There has been a video game industry in Liverpool since 1980, around the time the industry began to grow in popularity and technological capability (Anderton, 2014).

The case study explores whether the changes in leadership in LCR has affected the development of two high technology sectors during 2005-2015. The primary empirical evidence for this case study is drawn from 58 semi-structured interviews with firm owner managers and executives from the life science and video games industry within Liverpool City 
Region during 2010-13. Seven additional interviews were conducted with industry champions and strategic leaders of local and regional development agencies. Those respondents chosen in the local and regional development agencies were in leadership roles overseeing the development of the sector within the broader knowledge economy framework and urban redevelopment. The research used the Bionow (2012) industry directory verified via Companies House to identify life science firms. To identify video game firms the research started with web based searches, local industry reports and twitter feeds. Secondary qualitative and quantitative data was used to supplement the analysis and inform the broader economic and industrial context. Data has been collected from local news outlets, archives, company and agency websites and brochures collected from local conference and networking events.

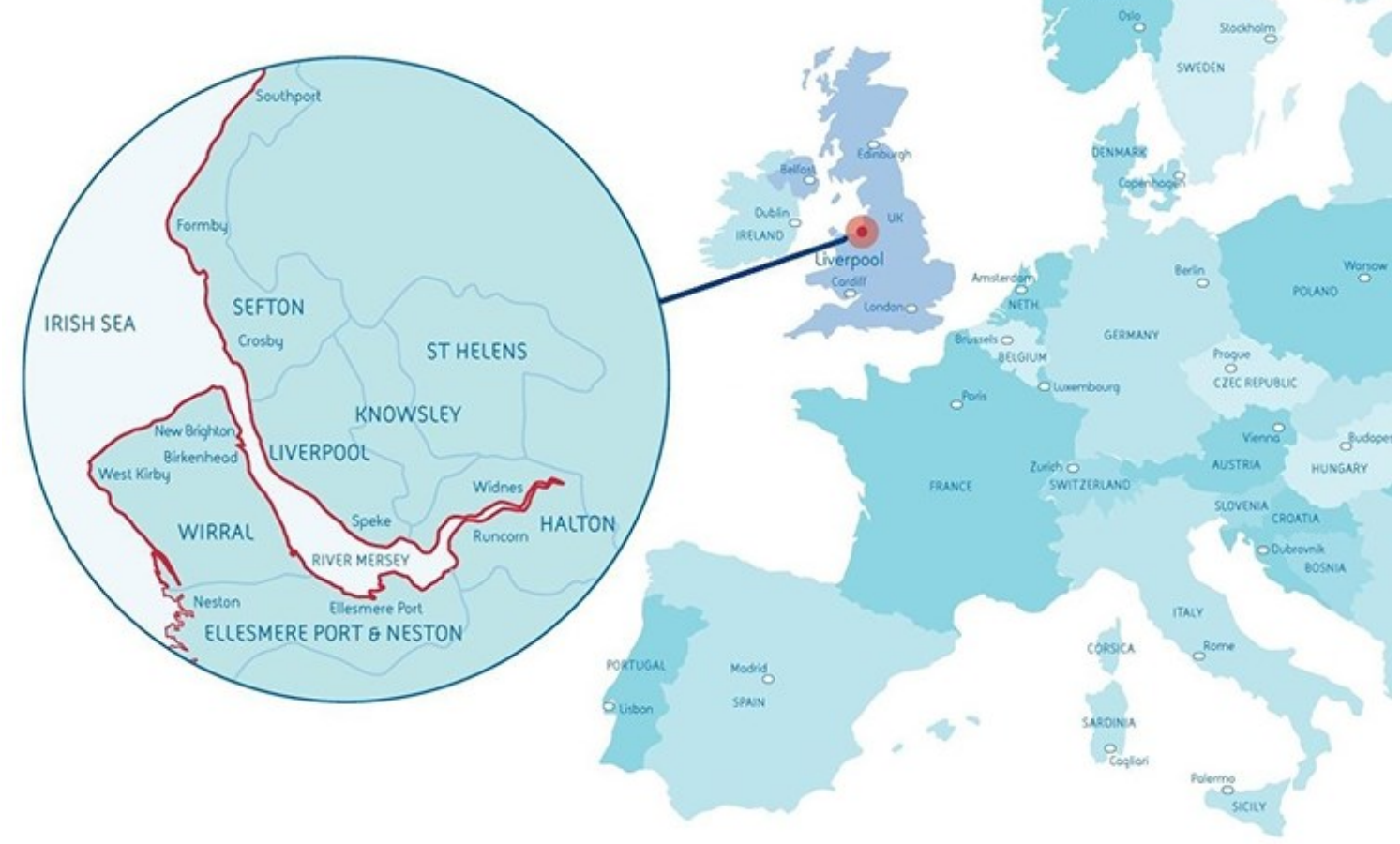

Figure 1 Liverpool City Region (Source: LCRLEP, 2014) 
The article begins with the turbulent history of the City of Liverpool through to the establishment of the Liverpool City Region. This outlines the frequent changes in institutional leadership and governance of the city region and its impacts on the industrial base.

\section{Leading from Managed Decline to Liverpool City Region}

Karlsen and Larra (2012) argue that place leadership is less about one individual, but more of a collective process developed over long periods. If long periods are needed to lead development and establish institutions with strong relationships between public and private actors, then we have to also consider what happens when change is triggered by contingent actors such as national government. This change in leadership affects networks of relationships with some falling apart or prospering in new spaces. These relationships will change, reform and adapt in various ways. These can be bottom up or top down changes. LCR has gained attention and changed through a number of prestige development and regeneration initiatives (Southern, 2014; Campbell, 2011). It is a city region that has seen enormous change in its most recent history (Southern, 2013). However, the path towards a knowledge economy has not been so straightforward for LCR. Liverpool's difficulties are predicated on path dependent issues embedded in its turbulent history in the 20th century. The trajectory of the current knowledge economy can be further understood through a reflection on the preceding events.

Southern (2014) notes that Liverpool had a very different industrial structure to most northern cities in England. Before, and at the beginning of, the 20th century Liverpool was shaped by the shipping trade between the UK and rest of the British Empire (Lane, 1986). In comparison, other northern cities where dominated by manufacturing activities. This would inevitably affect the way in which Liverpool reacted to industrial restructuring that was to come in the 1980's. However, in the post war era dominated by mass production and consumption, industrial policy took hold leading to a number of branch plant economies emerging in UK cities and regions throughout the 50's and 60's (Meegan, 2003). These tended to be manufacturing activities such as automobile production, textile and food processing. 
Yet, another pivotal turning point in Liverpool's history came in the 1970's through Britain's membership of the European Economic Community or now EU. This brought about two significant changes in the Liverpool economy: Firstly, it shifted the shipping trade from the Commonwealth Nations and North America to Europe, which was served by Southern and Eastern ports of England; Secondly, the new economic community coupled with globalisation made national boundaries more porous, allowing Multi-National Enterprise (MNE) activity to become increasingly mobile. This signalled the decline in competitiveness of the branch plant economy in Liverpool. This phenomena lead to the closure of many branch plants and other industries much earlier than in other northern cities (Southern, 2014). By the 1980's Liverpool was hampered with escalating unemployment rates and population decline, catalysed by the erosion of the ports and branch plants. This also left supporting service based activities in decline, where other regions and cities where seeing modest growth in the service sector (Allen and Massey, 1988).

The very infrastructure that kept Liverpool at the heart of the British Empire had almost collapsed by the end of the 1980's along with the post war industrial structures. Furthermore, enterprise in the city was increasingly squeezed out by larger corporations, furthering the decline of the city (Southern, 2014). Large manufacturers that relied on the port also closed their operations. However, pharmaceutical manufacturing had evolved out of the chemicals industry and continued production in the region. The industry was not reliant on the ports and could readily draw from the unskilled or semi-skilled labour markets at this time. At the beginning of the 1980's video game production was in its infancy, not requiring the levels of skill and development needed today. However, both industries where underdeveloped in Liverpool and the city faced further fiscal crisis as the economy contracted further throughout the 1980's. Frost and North (2013) have argued that the then Labour council began to fight against the decline marking a starting point of renewal for the city.

It was from the late 1980's and the beginning of the 1990's that local development agencies where formed such as The Mersey Partnership, Liverpool Vision (the first UK Urban Regeneration Company) and Government Office for Merseyside. Through these agencies, the city entered a stage of regeneration of its docklands and ports through the establishment of 
enterprise zones. This was followed by the European Structural Objective One funds that have to date provided $£ 700$ million of public sector funding to attract matched funding and further private sector investment for ten years from 1994. This significant initiative sparked interest in both life science and creative industries. Both the life science and creative industries where highlighted as key drivers to transform the city under Objective One. Both industries where seen as the big winners from Objective One funding (LCRLEP2016b). A further $£ 450$ million of EU and Government funds are to be spent in LCR to further the regeneration and industrial renewal of the city (LCRLEP, 2016). Following on from the EU Objective One with continued efforts to regenerate the entire city and the city region; Liverpool's local council, the NWDA and now LEP over the last decade have formulated a knowledge economy strategy. The strategy consists of four sector drivers of which two have been selected in this research:

- Life sciences

- Creative and digital industries

- Advanced manufacturing

- Financial and professional services

(LCRLEP, 2016a)

The life science and digital/creative industries were highlighted as a key driver to transform the city under Objective One. Succeeding Objective One; various local institutions have formulated a knowledge economy strategy placing the industries as two of four key sectors for development. Both sectors have evolved to this present day with many of the current developments taking place during 2005 -2015. The following section will outline the composition of the industries within the city region.

\section{Overview of the Two Sectors}

\section{Life Sciences}

There is a diverse range of firm activity in the LCR life science ecology (see Table 1). At the time of research, the 53 life science firms were active and present in LCR, giving a relatively small ecology compared to the South of England and USA. 
Table 1 Life Science firms by Activity in LCR

\begin{tabular}{ll}
\hline Activity & Number of Firms in 2013 \\
\hline Consultancy & 7 \\
Discovery (R\&D) & 13 \\
Diagnostic & 7 \\
Drug Manufacturing & 9 \\
Medical Devices & 8 \\
Other & 9 \\
\hline Total & 53 \\
\hline
\end{tabular}

The majority of firms have registered locations in designated science or innovation park developments (see Figure 2). These R\&D sites are largely the result of publicly financed hard infrastructure developments (Anderton, 2016).

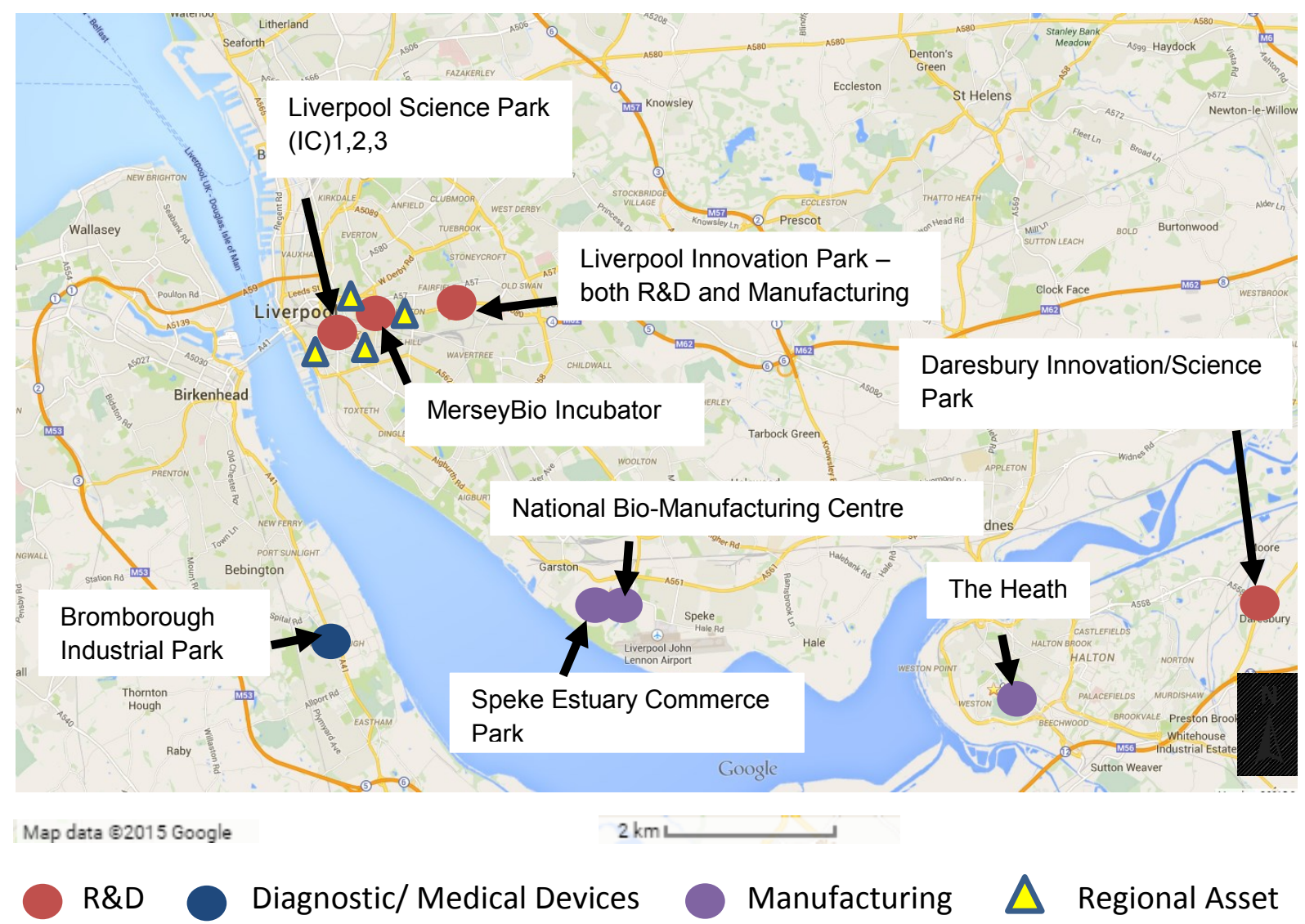

Figure 2 Life science firms by location

Local policy-makers have attempted to put in place a strategy to diversify this ecology towards more knowledge-intensive and high value-added activities such as R\&D. Hence, alongside the firms are a set of institutions that lead organisations have identified as assets to the industry 
and are regarded as complementing the development of the sector (Coe et al, 2004; Anderton, 2016). The most significant R\&D infrastructure intervention came through the development of MerseyBio Incubator located at the University of Liverpool in 2001. It emerged in the interviews that local policy makers identified a range of life science 'assets' in LCR; these are listed in Table 2 below along with their rationale for public support.

Table 2 Regional Assets in the LCR Life Science Ecology

\begin{tabular}{|c|c|c|}
\hline Asset & Policy rationale & Sector Focus \\
\hline University of Liverpool & $\begin{array}{l}\text { Offers education and } \\
\text { research across the } \\
\text { biosciences, medicine, } \\
\text { dentistry, health sciences, } \\
\text { tropical medicine and } \\
\text { veterinary science. }\end{array}$ & $\begin{array}{l}\text { The strategies recognise these } \\
\text { assets are sources and } \\
\text { infrastructures for innovation, } \\
\text { spin-out firms and world leading }\end{array}$ \\
\hline $\begin{array}{l}\text { Liverpool John Moore's } \\
\text { University }\end{array}$ & $\begin{array}{l}\text { Has a long record of expertise } \\
\text { in teaching, research, } \\
\text { consultancy and knowledge } \\
\text { transfer partnerships in life } \\
\text { sciences. }\end{array}$ & $\begin{array}{l}\text { research. All enrich the labour } \\
\text { market with graduates. } \\
\text { Graduate retention is low in the } \\
\text { region. Employers in the sector }\end{array}$ \\
\hline $\begin{array}{l}\text { Liverpool School of } \\
\text { Tropical Medicine }\end{array}$ & $\begin{array}{l}\text { The first institution in the } \\
\text { world dedicated to tropical } \\
\text { disease. The institutions } \\
\text { leads the field in research } \\
\text { against infections, } \\
\text { debilitating and disabling } \\
\text { diseases. }\end{array}$ & $\begin{array}{l}\text { readiness of graduates. } \\
\text { Many jobs in the sector require } \\
\text { post-graduate level education } \\
\text { and training. }\end{array}$ \\
\hline MerseyBio Incubator & $\begin{array}{l}\text { State-of-the-art facility for } \\
\text { developing biotechnology } \\
\text { businesses. Offers office and } \\
\text { laboratory space with access } \\
\text { to high value capital } \\
\text { equipment. }\end{array}$ & $\begin{array}{l}\text { The facility has been managed } \\
\text { by a consultancy firm with } \\
\text { expertise in biotechnology } \\
\text { commercialisation. } \\
\text { Limited in size with } 5 \text { companies } \\
\text { in } 2012 \text {. }\end{array}$ \\
\hline $\begin{array}{lr}\text { National } & \text { Bio- } \\
\text { manufacturing } & \text { Centre } \\
(\mathrm{NBC}) & \end{array}$ & $\begin{array}{l}\text { Received } £ 34 \text { million capital } \\
\text { investment to build state of } \\
\text { the art manufacturing } \\
\text { facilities and supporting } \\
\text { infrastructures such as road } \\
\text { and telecommunications } \\
\text { completed in } 2005 \text {. }\end{array}$ & $\begin{array}{l}\text { Largest concentration of } \\
\text { pharmaceutical manufacturers } \\
\text { in Europe. Hosts four } \\
\text { multinational firms that are } \\
\text { large employers in the region. } \\
\text { No R\&D activity recorded on this } \\
\text { site since } 1960 \text { 's. Seasonal } \\
\text { production with limited linkages } \\
\text { to city region firms. }\end{array}$ \\
\hline
\end{tabular}




\begin{tabular}{|c|c|c|}
\hline $\begin{array}{l}\text { Royal Liverpool } \\
\text { University Hospital and } \\
\text { other } \\
\text { hospitals/specialist } \\
\text { centres }\end{array}$ & $\begin{array}{l}\text { Large provider of front line } \\
\text { health services as well as } \\
\text { being a centre of excellence } \\
\text { and research for health } \\
\text { issues such as cancer, } \\
\text { neurology and pancreas } \\
\text { translation research. }\end{array}$ & $\begin{array}{l}\text { Undergoing } f 600 \text { million rebuild } \\
\text { designed to integrate bioscience } \\
\text { infrastructures. } \\
\text { Suffered delays due to changes } \\
\text { in national government. Due for } \\
\text { completion in summer } 2017 \text {. }\end{array}$ \\
\hline $\begin{array}{ll}\text { University } & \text { Technical } \\
\text { College (UTC) } & \end{array}$ & $\begin{array}{l}\text { The UKs first UTC dedicated } \\
\text { to health and life sciences. } \\
\text { Aims to develop a future } \\
\text { labour market of work ready } \\
19 \text { year olds for with skills to } \\
\text { work across the health and } \\
\text { life science sector. }\end{array}$ & $\begin{array}{l}\text { Bring together universities, } \\
\text { private sector specialist and } \\
\text { educators to develop bespoke } \\
\text { curricula for the city regions } \\
\text { young people. Established in } \\
2012 / 13 \text {. The first output of fully } \\
\text { trained students will not be until } \\
\text { approximately } 2018 \text {. }\end{array}$ \\
\hline
\end{tabular}

(Adapted from Anderton, 2016)

Together these assets and the firms have been mapped by LCRLEP (2015) in figure 3.

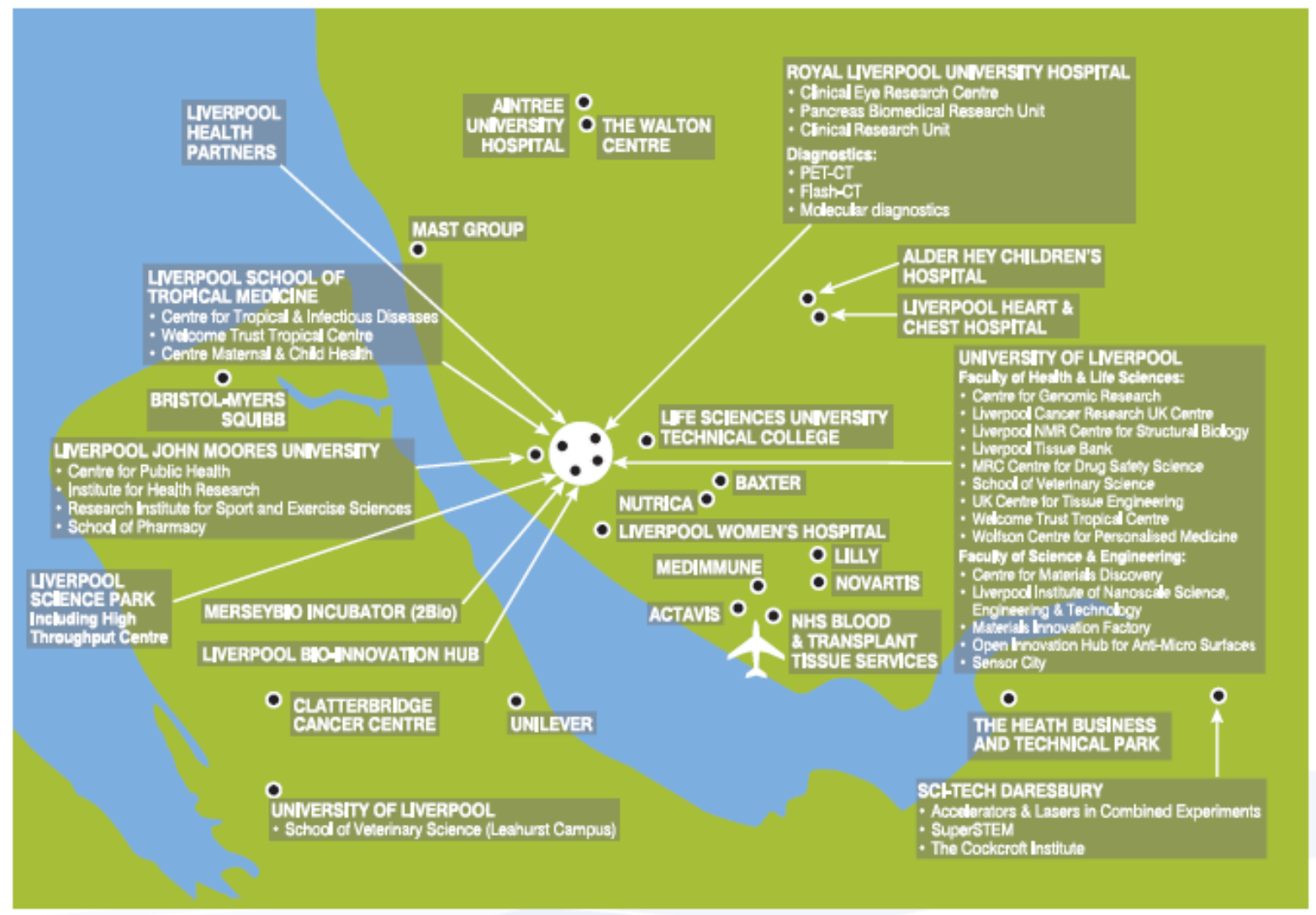

Figure 3 Map of Life Sciences in LCR (source: LCRLEP, 2015) 


\section{Video Games}

During this research, there were 30 firms identified as focusing on video game production, within the Liverpool City Region. These are shown table 3 based on their primary activity. NESTA (2014) has identified Liverpool as an entrepreneurial cluster with the potential for future growth within the UK.

Table 3 Video Games firms in LCR 2013

\begin{tabular}{ll}
\hline Firm Activity & Number of Firms \\
\hline Developer & 25 \\
Online Publisher & 1 \\
Sound & 1 \\
Visual art and & 1 \\
graphic & \\
Outsourcing & 1 \\
Multinational & 1 \\
Studio & \\
\hline Total & 30 \\
\hline
\end{tabular}

The video game firms in Liverpool are situated predominantly in a third sector and local development agency led initiative named the Baltic Triangle. This is located close to the waterfront in the historical port area. It is a brownfield development of several warehouses. This is shown in figure 4.

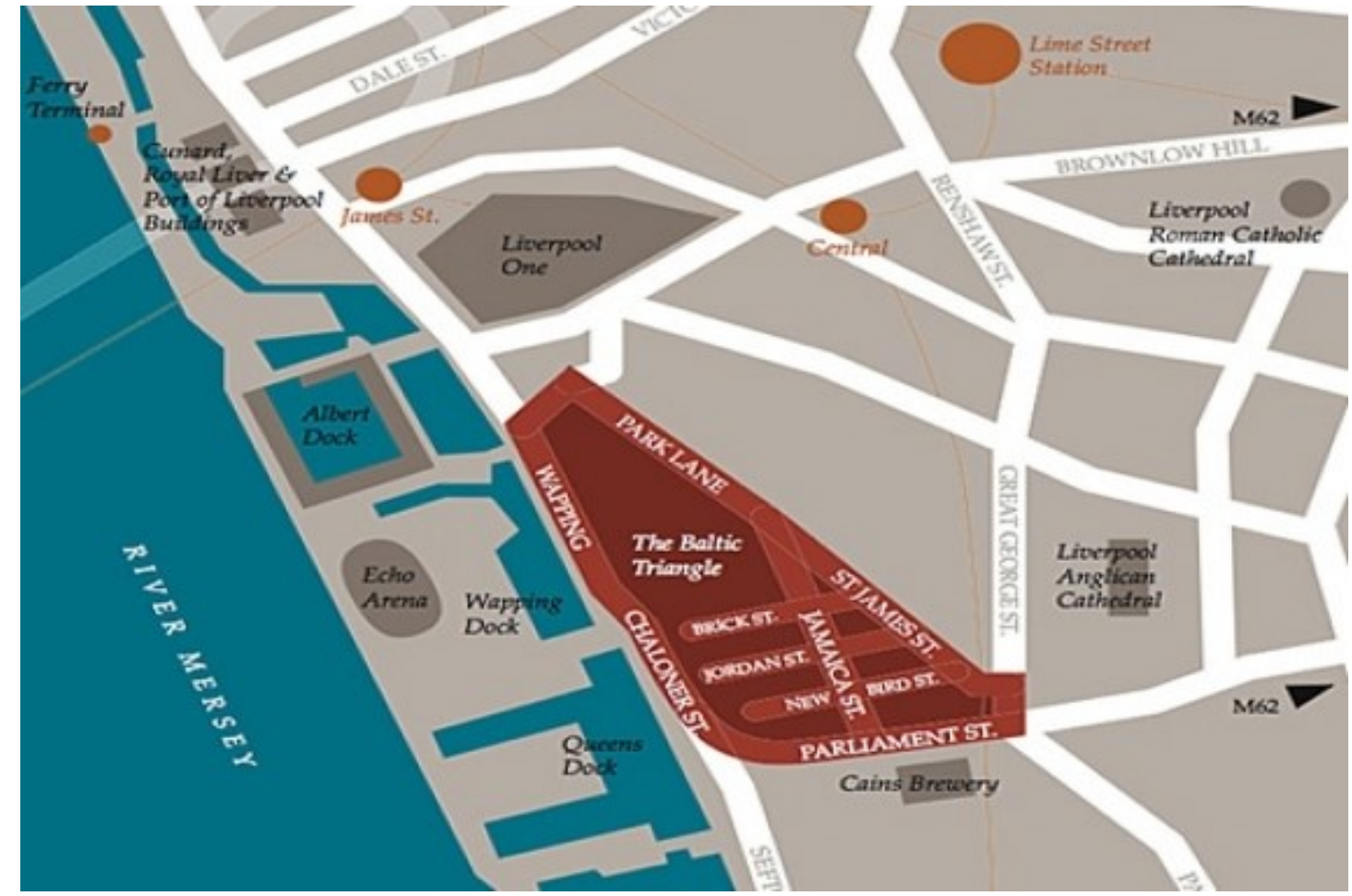


Figure 4 Baltic Triangle Map (Source: Baltircitriangle.co.uk)

Unlike the life sciences industry, fewer regional assets have a direct impact on the production ecosystem. However, there are identified assets that are contributing to the development of the labour market and industry. Four universities offer bespoke courses in digital and creative production at an undergraduate and post-graduate level. The industry, universities and public education sector have also joined forces to lead in the development of a University Technical College named The Studio. The Studio is dedicated to digital and creative industries with cocreated curricula for 14 -19 year olds. Other regional assets have developed from the business community with two taking leadership roles. These are not recognised by public leaders and are deemed to be hidden platforms embedded in a community of practice. These include the North West Indies Network and Indie Showcase, which encourage the business leaders to come together and share ideas, work and opportunities within the city regions ecosystem. This is an example of a business community of practice developing bespoke industry assets and leading in the regions development of soft infrastructures unaided by public leaders.

Policy makers have focused on redeveloping older spaces, which provide cheap rents for the sector. Decisions to redevelop is informed by business leaders and their preference to see affordable and characteristic re-development of older buildings. Unlike the life science industry there has been less public intervention and leadership in regards to the industries current development. However, there have been far more indirect intervention through public sponsored events that draw on the creative industries in the city. Furthermore, the Europe Capital of Culture 2008 was a key catalytic event which drew attention to Liverpool's prestige in this sector (OECD, 2015). The following sections will examine the changing leadership within the city region and how this has affected the two industries.

\section{Key Leaders/Actors in City Regional Development 2005 - 2010}

Both sectors have seen leadership from multiple actors and scales. There are two periods under analysis were we can understand and point out clear leadership change and its impact on the two sectors. Firstly, the period 2005 to 2010 and secondly, the period 2010 until 2015. 
During 2005 and 2010, there were six key actors in the development of these sectors. The organisations had individuals working within the industries and key sector leaders who had industry experience but worked in the public sector. Table 4 summaries the organisation and their sector focus.

Table 4 Lead Organisations 2005 - 2010

\begin{tabular}{|c|c|c|}
\hline Organisation & Purpose & Sector Focus \\
\hline $\begin{array}{l}\text { North West Regional } \\
\text { Development Agency }\end{array}$ & $\begin{array}{l}\text { The Agency was responsible } \\
\text { for the economic } \\
\text { development and } \\
\text { regeneration of the } \\
\text { Northwest of England. As a } \\
\text { business-led organisation, } \\
\text { the NWDA provided a link } \\
\text { between the needs of } \\
\text { businesses and Government } \\
\text { policies. Key agent in } \\
\text { manging European regional } \\
\text { Development Funds (ERDF), } \\
\text { government grants for } \\
\text { business and consultancy } \\
\text { through Business Link NW } \\
\text { and other bodies. }\end{array}$ & $\begin{array}{l}\text { Life sciences and } \\
\text { Digital/Creative industries. }\end{array}$ \\
\hline The Mersey Partnership & $\begin{array}{l}\text { A sub-regional agency } \\
\text { responsible for the } \\
\text { Merseyside region. Had a } \\
\text { limited role in comparison to } \\
\text { the NWDA and Liverpool } \\
\text { Vision. TMP has since } \\
\text { become the Local Enterprise } \\
\text { Partnership (discussed } \\
\text { later). }\end{array}$ & $\begin{array}{l}\text { General engagement with } \\
\text { knowledge economy } \\
\text { strategy and sector } \\
\text { developments. }\end{array}$ \\
\hline Liverpool Vision & $\begin{array}{l}\text { Partly funded by the NWDA } \\
\text { and the UKs first urban } \\
\text { regeneration company. Has } \\
\text { its own board of Directors } \\
\text { comprised of public and } \\
\text { private sector leaders. } \\
\text { Tasked with Liverpool City } \\
\text { Region regeneration and } \\
\text { international marketing of } \\
\text { knowledge economy } \\
\text { sectors. During this period, } \\
\text { the organisation was a }\end{array}$ & $\begin{array}{l}\text { Life Science } \text { and } \\
\text { Digital/Creative local city } \\
\text { champion. }\end{array}$ \\
\hline
\end{tabular}




\begin{tabular}{|c|c|c|}
\hline & $\begin{array}{l}\text { public-private collaboration } \\
\text { in the City of Liverpool. }\end{array}$ & \\
\hline Baltic Creative & $\begin{array}{l}\text { A CIC set up in } 2009 \text { that } \\
\text { supports the general } \\
\text { creative sector. The } \\
\text { organisation provides a } \\
\text { variety of spaces for the } \\
\text { digital/creative firms, } \\
\text { meeting venues, } \\
\text { conferencing facilities as } \\
\text { well as playing a part in the } \\
\text { regeneration of the city and } \\
\text { furthering through } \\
\text { development economic } \\
\text { creative enterprise. }\end{array}$ & Digital/Creative sector. \\
\hline Mersey Bio & $\begin{array}{l}\text { A private consultancy lead } \\
\text { initiative with initial funding } \\
\text { from the NWDA to build the } \\
\text { facility, and supported by } \\
\text { Liverpool Vision, TMP and } \\
\text { the University of Liverpool. } \\
\text { Aimed at supporting and } \\
\text { accelerating the } \\
\text { development of new R\&D } \\
\text { firm start-ups in Life science } \\
\text { industry. Ran as a } \\
\text { commercial site for business } \\
\text { development. }\end{array}$ & $\begin{array}{l}\text { Life Science - targeting early } \\
\text { stage R\&D firms. }\end{array}$ \\
\hline Eden BioDesign & $\begin{array}{l}\text { Lead a bid to develop the } \\
\text { National Biomanufacturing } \\
\text { Centre. A hard infrastructure } \\
\text { investment located in Speke, } \\
\text { Liverpool. Houses the largest } \\
\text { concentration of drug } \\
\text { manufacturers in Europe. }\end{array}$ & $\begin{array}{l}\text { Life science - specialist in } \\
\text { biomanufacturing. Limited } \\
\text { research and development. }\end{array}$ \\
\hline
\end{tabular}

During this period, the life sciences industry saw growth underpinned by public investment and grants, increasing the number of new firm start-ups and spinouts from universities. Alongside the firms, institutional support was strong for the sector with the NWDA developing a bespoke organisation, Bionow, as an industry champion for the North West.

"One of the fabulously successful initiatives in the previous RDA, the North West Development Agency, was a group called Bio Now, and Bio Now created huge amounts 
of opportunities for both the business community, pharmaceutical firms and small fledgling business or folks with an interest in creating them to come together, and that was a hugely successful undertaking led by an ex industry professional" (Interview Drug Manufacturer 5 10/09/12)

The life science industry had four multinational pharmaceutical firms in the city region focusing on drug manufacturing only. For the video games industry, three large multinational studios acquired existing firms growing the industry in terms of employment but maintaining the number of firms to approximately 12 in 2009. Post 2010 the changes in governance and factors from outside the city region changed the composition of these industries leading to a change in how the knowledge economy developed.

\section{Dealing with Change in Leadership post 2010: Leading an illusion?}

Liverpool has not been immune to the change in national government and subsequent realignment of governance structures to the sub-regional level. City regions have now become the UKs preferred unit of analysis in regards to economic development and devolution. The implications for Liverpool have been noticeable in the leadership of these two sectors. Most noticeable is the dissolving of the regional development agency NWDA. This has had a knock on effect to other institutional leaders who received part or full funding form the agency. The NWDA brought coherent multi-scalar broking abilities to the region which began to dissolve immediately after the coalition governments decision to remove regional development agencies (RDA's). The period 2010 to 2015 has seen the demise of the regional development agency and the rise of alternative sub-regional economic development agencies, Local Enterprise Partnerships (LEPs) (See table 5).

Table 5 Leading Organisations post 2010

\begin{tabular}{|l|l|l|}
\hline Organisation & Purpose & Sector Focus \\
\hline Local Enterprise Partnership & City regional agency tasked & Life Science and \\
& with economic development & Digital/creative \\
with the Liverpool City & \\
& $\begin{array}{l}\text { Region. Fewer resources } \\
\text { than the NWDA but more }\end{array}$ & \\
\hline
\end{tabular}




\begin{tabular}{|c|c|c|}
\hline & $\begin{array}{l}\text { focused what was the } \\
\text { Mersey side region. }\end{array}$ & \\
\hline Liverpool Vision & $\begin{array}{l}\text { Now a fully public } \\
\text { organisation under the } \\
\text { Mayor's office for } \\
\text { regeneration } \\
\text { development. and } \\
\text { organisation aims to attract } \\
\text { new investment and hosting } \\
\text { international events. }\end{array}$ & $\begin{array}{l}\text { Life Science and } \\
\text { Digital/creative - there have } \\
\text { been management and staff } \\
\text { changes }\end{array}$ \\
\hline Technical & $\begin{array}{l}\text { Set up by Government } \\
\text { initiative in } 2013 \text { to bring } \\
\text { together private firms, } \\
\text { universities and public } \\
\text { sector education providers } \\
\text { to deliver bespoke courses } \\
\text { for labour market } \\
\text { development in } \\
\text { digital/creative and life } \\
\text { sciences. }\end{array}$ & $\begin{array}{l}\text { Life Science and } \\
\text { Digital/creative }\end{array}$ \\
\hline Consultancies & $\begin{array}{l}\text { Private firms set up to bridge } \\
\text { the knowledge and capital } \\
\text { flow gaps for early start up } \\
\text { R\&D firms in the life science } \\
\text { sector. Replaced the role of } \\
\text { the NWDA as a broker in the } \\
\text { industry. }\end{array}$ & $\begin{array}{l}\text { Life Sciences only. Industry } \\
\text { specialist. }\end{array}$ \\
\hline Prominent Firms & $\begin{array}{l}\text { Three identified business } \\
\text { leaders, who are former } \\
\text { studio managers of the MNE } \\
\text { before closures. They are } \\
\text { now co-ordinating } \\
\text { networking events and } \\
\text { online communities beyond } \\
\text { the boundary of the } \\
\text { organisation to the city } \\
\text { region level. }\end{array}$ & $\begin{array}{l}\text { Video game - two are } \\
\text { leaders of the Indie } \\
\text { Showcase and north West } \\
\text { Indies. One sits on the LEP } \\
\text { Digital/Creative Board. }\end{array}$ \\
\hline $\begin{array}{l}\text { North West Indies and the } \\
\text { Indie Showcase }\end{array}$ & $\begin{array}{l}\text { Business lead initiatives to } \\
\text { support the } 30+\text { firms in the } \\
\text { video game industry. North } \\
\text { West Indies is an online } \\
\text { platform for posting jobs, } \\
\text { sharing information on } \\
\text { projects and requesting local } \\
\text { partners to assist on } \\
\text { projects. Indie Showcase is a } \\
\text { network that organises small }\end{array}$ & $\begin{array}{l}\text { Digital/Creative - only video } \\
\text { game related firms }\end{array}$ \\
\hline
\end{tabular}




\begin{tabular}{|l|l|l|}
\hline & $\begin{array}{l}\text { conferences and networking } \\
\text { opportunities within the city } \\
\text { region. }\end{array}$ \\
\hline
\end{tabular}

However, the effect on both of the industries has been significantly different. Each has now embarked on opposing trajectories of development. New lead institutions lost many of the networked individuals and mechanism that formally occupied the NWDA and acted as brokers for firms to establish themselves and connect them into investment and knowledge flows from other scales, notable the EU. The new LEP has not inherited many of the networked structures that the RDA's had previously built and maintained. Personal contacts were lost and the new governance structure brought about new ways of engaging with industry. The LEP did inherited a plan and strategy from its predecessors to press ahead with the development of the city region's knowledge economy framework. Since 2012/13 the LEP has restructured the ways interacts with industry, setting up industry specific boards, which meet a varying periods in a year. Their mission states:

Our Mission is to drive growth in the Liverpool City Region. We bring together all sectors to create one powerful voice to develop economic priorities, engage with government and secure investment. That enables us to support business and key sector growth, enhance skills, create jobs and ensure the future prosperity of the region. Our Vision is to be a globally connected City Region delivering sustainable growth, opportunity and prosperity for people and businesses. (LCRLEP, 2016a)

When government support has become more centralised and austere times have meant a reduction in regional development funds across the UK, the two sectors have entered different pathways. The life sciences have previously benefited from expensive hard investments from the public sector (Anderton, 2016). This has boosted the regeneration of particular areas in the city region. However, the vision of regeneration through hard infrastructure development only fails to consider the development of soft infrastructures such as networking, human capital and business support. For example, it was noted on several occasions that firms did not know how to commercialise their intellectual property. 
"This idea of spin outs or doing something with your IP was something that sat there and you know people had it in documents but it was never, ever taken seriously. I think that was part of the problem." (Interview Consultancy Firm 3, 09/05/12)

The industry was lacking soft infrastructures, particularly business support and networking locally and extra-locally, that could culminate in a community of practice for the sector. Juxtaposed to this is the video games industry has had limited direct public leadership in the growth and development of the sector. Post 2010 the sector saw the closure of the three multinational studios despite pubic leaders' efforts to engage with them to remain. The onset of mass redundancies lead to entrepreneurial activity and business leaders embarking on new firm start-up utilising their redundancy packages as start-up capital.

"So we basically formed [a company] immediately after Bizarre Creations was closed, so February this year, yeah, so Bizarre was closed on the $18^{\text {th }}$ February and pretty much the Monday after, so the $21^{\text {st }}$, we were up and running, kind of! Without any contracts or being able to pay staff, a group of us just decided like you know we'll start a new company, we're not going to get paid, so we'll do it, we'll give ourselves like three months of not getting paid to kind of see how things go basically, and try and win a contract" (Interview Developer 8, 30/11/11)

The developer is illustrating the lower resource requirements, both financial and hard infrastructure, required in the start-up and development of new businesses. The pace of development was aided by the relative wealth of labour and technical knowledge readily available in LCR post -closure of the three MNEs in 2010/11. On top of this, two firms lead the development of new bespoke soft infrastructure platforms that complemented the ecosystem. These include North West Indies and Indie Showcase. These platforms are examples of soft infrastructures, which can be hard to establish without an existing community of practice embedded within the local. Leaders need to consider developing and institutionalising such infrastructures alongside the development of hard infrastructures. Equally, leaders must understand their industry and the abilities within their locality. These networks are a response to the local firms needing to stick together to evolve the community of practice. 
'[North West Indies] was initially just a private mailing list for people to just e-mail round and help each other. And it kind of spiralled bit, you know, people told people and people told people. At the minute ... And then we started to get a little bit of kind of proper coverage you know, it was in the Liverpool Post, Euro Gamer did a feature on what happened after Bizarre closed and they were interested in hearing about North West Indies, so I was featured on one of their video presentations they do. We're in touch with a couple of other little journalists and stuff. But you know we've been in the paper a couple of times. And now it's, I think there's like 60 of us representing a, there's over 30 companies' (Interview Developer 9, 13/12/11)

For life sciences, Liverpool City Region has not been seen as a place to do life science, unlike in the video games sector where the big firm names have established a reputation of good game development attracting major events and others to work here.

"There seems to be a lack of awareness of what's in the North West because when you say life sciences people are drawn to think of London and Oxbridge because of their reputations" (Interview Public organisation 2, 05/08/10)

The MNEs in the LCR life science industry have not given the same gravitas in terms of reputation to attract or spawn new research and development firms. As one consultancy firms stated;

'So the Government a few years ago decided they were going to invest in bio manufacturing, high tech manufacturing, for the life science industry. And I think Liverpool more closely represents an area like that than it does say a Cambridge or a Manchester or you know Cambridge Massachusetts. The National Biomanufacturing Centre became a 40 million investment in Liverpool. ' (Interview Consultancy Firm 3, $09 / 05 / 12)$

This is attributed to their historical activities in LCR and how the wider industry is organised. For example, life science manufacturing is classed as a different part of the business for the 
three MNE interviewed. Internally they have to pitch for work to the headquarters using quasi-market mechanisms. The evidence also revealed that R\&D firms are struggling to attract new investment and the individuals with the specialist knowledge to relocate to the city. However, several owner-managers highlighted Liverpool as a strategic place for their firms to locate. The reason behind this was the availability of funding from various levels of government. This funding came with conditions that firms establish or remain in LCR. Respondents noted the city is now regarded as a 'place to do life sciences'. Hence, several firms registered themselves in LCR and used facilities on an ad-hoc basis, yet had permanent premises elsewhere creating an illusion of presence (Anderton, 2014).

"so it really doesn't matter where we are, well for the individuals it doesn't matter where we are, but for pharmaceuticals looking in to [company], for us to be in the life sciences presence is important.... It's absolutely about perception" (Interview Consultancy Firm 3 09/05/12)

Firms where merely trading off the place-based perception and taking advantage of funding in LCR rather than contributing towards its development.

In the video games industry, many of the new owner managers have been able to take advantage of the existing soft infrastructures inherited from their former employer. Additionally, comparing both industries to other studies, the critical mass of firms is not large enough to allow for a fully integrate ecosystem of local co-production. Firms in the early stages of development have limited scope for cross fertilisation or the resources to host events and establish large intra-firm projects. In the life sciences industry, the communities of practice that we expect to emerge are not developing at the same pace as in the video games sector since the withdrawal of the NWDA and numerous funding mechanism it brought to the city region (Cohendet et al, 2010). The NWDA had industry specialists capable of bridging the gaps between the big pharmaceutical firms and the smaller dedicated research firms, again acting as a broker between ties. These brokers began disappearing with the abolition of the NWDA. Bionow still exists as a commercial regional membership service with no direct policy influence. Similar institutions were in place for the wider digital/creative communities in Liverpool, however, post 2010 the video games industry lost three major 
players as well as support from NWDA and various city region-based organisations partly or fully funded from the NWDA. Yet is has continued to develop through entrepreneurship and private leadership within the sector.

\section{Institutions and Infrastructures for Economic Development}

Institutions can play a key role in economic development. This research has highlighted that there are two competing perspective emerging from leadership shown in the development of the two industries. Henry and Pinch (2001) argue that as well as institutional thickness, institutional thinness can also be effective in particular places. Institutional thinness is contrasting to the four key components and process of institutional thickness. Table 6 combines both the institutional thickness and thinness concepts to the life science and video game industry (Henry and Pinch, 2001; Amin and Thrift, 1994, 1995).

Table 6 Institutional thickness and thinness

\begin{tabular}{|c|c|c|}
\hline & Characteristics & Life Science \\
\hline $\begin{array}{l}\text { Institutional } \\
\text { Thickness }\end{array}$ & $\begin{array}{l}\text { Strong institutional presence } \\
\text { High levels of interaction } \\
\text { amongst institutional networks } \\
\text { Structures of domination and } \\
\text { patterns of coalition } \\
\text { Mutual awareness of a common } \\
\text { enterprise of industrial purpose } \\
\text { amongst participant and } \\
\text { institutions }\end{array}$ & $\begin{array}{l}\text { Has a growing institutional presence } \\
\text { showing many of the outcomes of the } \\
\text { favourable institutional conditions. } \\
\text { The life science ecology has been in the } \\
\text { process of coordinated } \\
\text { institutionalisation for a decade, } \\
\text { involving institutions from multiple } \\
\text { scales but with the ability and a desire } \\
\text { at the city level to continue growing a } \\
\text { competitive life science ecology. } \\
\text { There has been a balance of } \\
\text { institutional and firm lead initiative as } \\
\text { well as co-ordination between both. }\end{array}$ \\
\hline
\end{tabular}




\begin{tabular}{|c|c|c|}
\hline & & $\begin{array}{l}\text { Change has left fewer public } \\
\text { lead/supported institutions. }\end{array}$ \\
\hline & & Video Games \\
\hline $\begin{array}{l}\text { Institutional } \\
\text { Thinness }\end{array}$ & $\begin{array}{l}\text { Low institutional presence } \\
\text { Low levels of interaction with } \\
\text { institutions but high among firms } \\
\text { Collective structures that } \\
\text { emerge through inter-firm co- } \\
\text { ordination rather than from } \\
\text { institutional efforts } \\
\text { More of a process of } \\
\text { institutionalisation rather than } \\
\text { the presence of institutional } \\
\text { infrastructures }\end{array}$ & $\begin{array}{l}\text { The video games industry is lacking } \\
\text { many of the co-ordinated institutional } \\
\text { processes and components. } \\
\text { However, there is an effort that stems } \\
\text { from collective action from the firms } \\
\text { themselves that is achieving many of } \\
\text { the outcomes of favourable } \\
\text { institutional thickness conditions. } \\
\text { There are collective structures that are } \\
\text { emerging through the pro-activeness } \\
\text { of firms. The Indie Showcase and the } \\
\text { North West indies are two firm lead } \\
\text { initiatives with no public sponsorship } \\
\text { showing a collective representation, as } \\
\text { well as a mutual awareness of } \\
\text { enterprise and industrial purpose. } \\
\text { production activity. }\end{array}$ \\
\hline
\end{tabular}

(Adapted from Amin and Thrift, 1994, 1995 and Henry and Pinch, 2001)

Table 6 has summarised the difference between the two sectors and how each have different supports put in place by public leadership during the period 2005 to 2010 . There is some crossover into the period 2010 to 2015 with some institutions becoming stronger and more prevalent in the sectors shown in table 5 . However, there is a clear contrast between a life 
science sector that has taken large amount of public money to develop key hard infrastructures, whereas the video games sector has seen leadership stem directly from entrepreneurial and business leadership with limited dependency on public support and leadership.

\section{Discussion and Implications}

Significant EU and UK investment went into life science hard and soft infrastructures in LCR lead by the North West Development Agency (NWDA). These were targeted at increasing the R\&D capacity of the ecosystem, which is otherwise dominated by pharmaceutical drug manufacturing. However, in 2010 the NWDA was abolished with the loss of its leadership and key sector agents. Funds have since shifted to alternative centralised grant schemes. The result of this change in leadership and funding has left several firms stalled or having to reassess their goals and objectives. As Rodríguez-Pose and Di Cataldo (2015) argued the weaker the governmental institutions or in this case removal has affected the innovative yield of the region and in this case the furthering of industry development. Due to the dominance of the NWDA from 2005 to 2010, other institutions devoted fewer resources to the sector relying more on the leadership of the NWDA. This is reflected in the scale of resources (time, money, human capital, knowledge) needed to support such a complex and expensive industry. Hence, the realignment of economic development to the sub region Local Enterprise Partnerships (LEPs) has resulting in the loss of some softer regional infrastructures such as networking, expertise and knowledge exchange.

The analysis shows that despite the heavy investment in infrastructures lead by the NWDA, it is the firms that are now having to invest and lead themselves in the development of city region soft infrastructures, such as networking and knowledge exchange relating to on-going business issues, where they share a common experience. This has resulted in low levels of connectivity between firms on a product or project basis in LCR. However, firms are mobilising themselves across space to open up channels in which soft infrastructures can emerge as global pipelines to support the development of the ecology in the city region (Maskell et al, 2006). Consultants are also playing a key role in bridging the soft infrastructure gaps in 
product and project knowledge by lending their experience and global pipelines to firms in LCR (Anderton, 2014; Sotarauta, 2015).

The video games industry has not been as affected by the changes in leadership. They have benefited from organised private leadership that capitalised on the needs and abilities of the region in the wake of the multinational studios departures. It's lack of dependence on public leadership and subsequent funding has allowed the sector to grow form 12 firms to over 30 in a five year period. They have harnessed their inherited norms and routines from their former employers and established new institutions to foster growth within the region. They have lead with other actors in the region to develop the resilience of the industry. Business leaders have self-organised to develop on soft infrastructures within and beyond LCR as well as taken up positions on the new LEP boards.

\section{Conclusions}

In conclusion, this paper has examined the impact of changes in place-based leadership on the development of two knowledge intensive industries, video games and life sciences, in Liverpool City Region. Two trajectories emerged for these industries. The video games industry was able to self-organise through business leadership building on their strong soft infrastructures and thin institutional base. The life sciences are more dependent on public/governmental leadership, which has brought the city and industry several large hard infrastructure investments, but limited soft infrastructure development. The removal of lead institutions need careful planning in peripheral regions so that the attributes of the brave, visionary individuals and innovative networks are inherited in the new institutions rather than lost (Sotarauta, 2005). Peripheral city regions need clear narratives backed up with strong multi-agency leadership, recognising development agencies, firms and consultants in the region that are able to work across multiple scales bridging knowledge gaps in production. For high technology sectors, development should specialise in fewer core competencies rather than breadth of activities to bring about a connection to a positive place image that yields an enhanced perception and barriers for products from competing areas. 
Leaders should also be conscious of resilience when embarking on large-scale projects to develop capital-intensive industries. We have seen in the life sciences industry that leaders supporting the development of such industry were not considering the labour market development lag time despite having mechanisms to improve it such as the UTC. In creating a path renewal of this industry into $R \& D$, leaders had trapped themselves in path extension with manufacturing still dominating the sector. Juxtaposed in less capital-intensive industries such as the video games, public leaders need to capitalise and support private leadership and initiatives so they are embedded in the education system, labour market and industrial base of the city region. Hence, there has to be a thorough assessment by city leaders of the type of industry they support based on what currently exists locally, along with an understanding of that particular industry ecosystem. Leaders need to be cautious when developing industrial policy that takes large public and/or private capital investments. Policy makers need to consider how they can develop and embed soft infrastructures that allow an industry to support and be involved with leading change within their particular locale.

\section{References}

Allen, J., \& Massey, D. B. 1988. The economy in question (Vol. 1). Sage Publications Ltd.

Amin, A., \& Thrift, N. 1994. Holding down the global. Oxford, Oxford University Press

Amin, A. and Thrift, N., 1995. Globalization, institutions, and regional development in Europe. Oxford university press.

Anderton, D. 2014. Firm Ecologies: Life science and video game industries in Liverpool. PhD Thesis. University of Liverpool.

Anderton, D. 2016. Science in the city region: establishing Liverpool's life science ecology. Regional Studies, Regional Science, 3(1), pp.437-444.

Bathelt, H. and Glückler, J., 2011. The relational economy: Geographies of knowing and learning. Oxford University Press.

Beer, A. and Clower, T., 2014. Mobilizing leadership in cities and regions. Regional Studies, Regional Science, 1(1), pp.5-20.

Bionow. 2012. Bionow Directory, Benham Publishing Limited, Liverpool 
Bristow, G., Healy, A. and Norris, L., 2013. Economic crisis: Resilience of regions. Applied Research, 124, p.2012.

Bryman, A., 2004. Qualitative research on leadership: A critical but appreciative review. The leadership quarterly, 15(6), pp.729-769.

Campbell, P. 2011. 'A Catachresis of Creativity. University of Liverpool Management School'. Liverpool, University of Liverpool. Doctor of Philosophy.

Coe, N. M., Hess, M., Yeung, H. W. C., Dicken, P., \& Henderson, J. 2004. "'Globalizing' regional development: a global production networks perspective." Transactions of the Institute of British Geographers, 29(4), 468-484.

Cohendet, P, Grandadam, D and Simon, L. 2010. "The Anatomy of the Creative City", Industry and Innovation, 17(1), 91-111

Collinge, C. and Gibney, J., 2010. Connecting place, policy and leadership. Policy studies, 31(4), pp.379-391.

Cooke, P., Boekholt, P., \& Tödtling, F. 2000. The governance of innovation in Europe. Pinter, London.

Foster, K.A. 2007. A Case Study Approach to Understanding Regional Resilience (working paper). Institute of Urban \& Regional Development.

Frost, D., \& North, P. 2013. Militant Liverpool: a city on the edge. Oxford University Press.

Gibney, J., 2010. Knowledge in a "shared and interdependent world": implications for a progressive leadership of cities and regions. European Planning Studies, 19(4), pp.613-627.

Gibney, J., 2012. Leadership of place and the dynamics of knowledge. Leadership and Change in Sustainable Regional Development, 60, p.20.

Henry, N. and Pinch, S., 2001. Neo-Marshallian nodes, institutional thickness, and Britain's 'motor sport valley': thick or thin?. Environment and Planning A, 33(7), pp.1169-1183.

Huang, H., \& Xu, C. 1999. Institutions, innovations, and growth. American Economic Review, 438-444.

Isaksen, A. 2015. Industrial development in thin regions: trapped in path extension?. Journal of Economic Geography, 15, 585-600.

Karlsen, J. and Larra, M. 2012. Emergence of shared leadership in the Basque Country, in Sotarauta M., Horlings L., and Liddle J. (eds.). Leadership and Change in Sustainable Regional Development, Routledge, Abingdon

Lane, T. 1986. We are the Champions: Liverpool vs the 1980s'. Marxism Today, 30, 8-11. 
LCRLEP. 2014. Economy, Available:

http://www.liverpoollep.org/liverpool city region/economy.aspx, Accessed: 12/1/15

LCRLEP. 2015. Life Sciences: A Skills for Growth Agreement, Available:

https://www.liverpoollep.org/wp-content/uploads/2015/06/wpid-Icr-skills-for-growth-agreementlife-sciences-01-2015.pdf , Accessed: 12/10/16

LCRLEP. 2016a. Knowledge Economy, Available:

http://www.liverpoollep.org/liverpool city region.aspx, Accessed: 12/1/15

LCRLEP, 2016b. EU STRUCTURAL AND INVESTMENT FUNDS STRATEGY 2014-2020, available: https://www.liverpoollep.org/wp-content/uploads/2015/04/Final-ESIF-Strategy-4-February-2016-toDCLG.pdf , last accessed 01/12/16

Liddle, J., 2015. Public and Third Sector Leadership: Experience Speaks. International Journal of Public Leadership.

Liddle, J., Gibney, J., Sotarauta, M. and Beer, A., 2016. Exploring Varieties of Leadership in Urban and Regional Development. Regions Magazine,302(1), pp.12-13.

Liddle, J., 2016. Aligning vertical structures and horizontal relationships: collaborative leadership and accountability mechanisms to enhance economic growth in England. International Review of Administrative Sciences

Liddle J, Gibney J, Sotarauta M, et al. 2016. Exploring varieties of leadership in urban and regional development. Regions Magazine 302(1): 12-13.

Liverpool City Region.co.uk. 2011. Liverpool City Regions Knowledge Economy: Delivering New opportunities for Growth, available: https://www.liverpoollep.org/wpcontent/uploads/2015/06/wpid-Icr-knowledge-economy-plan-summary-02-2011.pdf , last accessed $01 / 12 / 16$

Maskell, P. Bathelt, H. \& Malmberg, A. 2006. "Building global knowledge pipelines: The role of temporary clusters", European Planning Studies, 14(8), 997 - 1013.

Meegan, R. 2003. Urban regeneration, politics and social cohesion: The Liverpool case. Reinventing the City? Liverpool in Comparative Perspective, 53-79.

Neffke, F., Henning, M., \& Boschma, R. 2011. How do regions diversify over time? Industry relatedness and the development of new growth paths in regions. Economic Geography, 87(3), 237265. 
NESTA, 2014. A map of the UK Games Industry, Available:

http://www.nesta.org.uk/sites/default/files/map uk games industry wv.pdf, last accessed $12 / 11 / 16$

OECD. 2015. Local Economic Leadership, Paris, OECD.

Pike, A., Rodríguez-Pose, A. and Tomaney, J., 2006. What kind of local and regional development and for whom?. Regional studies, 41(9), pp.1253-1269.

Rodríguez-Pose, A., 2013. Do institutions matter for regional development?. Regional Studies, 47(7), pp.1034-1047.

Rodríguez-Pose, A., \& Di Cataldo, M. 2015. Quality of government and innovative performance in the regions of Europe. Journal of Economic Geography, 15, 673-706.

Simmie, J. and Martin, R., 2010. The economic resilience of regions: towards an evolutionary approach. Cambridge journal of regions, economy and society, 3(1), pp.27-43.

Sotarauta, M., 2005. Shared leadership and dynamic capabilities in regional development. Regionalism contested: Institution, society and governance, pp.53-72.

Sotarauta, M., 2010. Regional development and regional networks: The role of regional development officers in Finland. European Urban and Regional Studies, 17(4), pp.387-400.

Sotarauta, M., 2015. Leadership and the City: Power, Strategy and Networks in the Making of Knowledge Cities (Vol. 92). Routledge

Sotarauta, M., Beer, A. and Gibney, J., 2017. Making sense of leadership in urban and regional development. Regional Studies, 51(2) pp.187-194

Sotarauta, M. and Beer, A., 2017. Governance, Agency and Place Leadership: Lessons from a CrossNational Analysis. Regional Studies, 51(2) pp.1-14.

Sotarauta M., Horlings L., and Liddle J. (eds.). 2012. Leadership and Change in Sustainable Regional Development, Routledge, Abingdon

Southern, A. 2013. Cities regeneration processes: the role of entrepreneurs, residents and tourists September 19th-20th 2013 University of Le Havre (France).

Southern, A. 2014. "Enterprise, wealth creation and place: A case study of the Liverpool cityregion. Enterprising Places: Leadership and Governance Networks", Contemporary Issues in Entrepreneurship Research, 3, 227-257.

Stimson, R.J., Stough, R. and Salazar, M., 2009. Leadership and institutions in regional endogenous development. Edward Elgar Publishing. 
Van Winden, W., 2008. Urban governance in the knowledge-based economy: Challenges for different city types. Innovation, 10(2-3), pp.197-210. 